This is the version of the article accepted for publication in Past and Present published by Oxford University Press: https://doi.org/10.1093/past/gtu028

Accepted version downloaded from SOAS Research Online: http://eprints.soas.ac.uk/21524

\title{
Colonial Histories of Heritage: Legislative Migrations and the Politics of Preservation
}

\section{Paul Basu and Vinita Damodaran}

In recent years there has been an increasing body of scholarship concerned with the history of heritage legislation. Whereas such archival forays have typically provided merely contextual background for the discussion of current heritage resource management policies, ${ }^{1}$ the historical analysis of heritage legislation also provides insight into the broader social, political and, indeed, economic values codified in such laws. ${ }^{2}$ Most often this work is framed within a national context. ${ }^{3}$ This reflects the fact that these laws necessarily passed through specific national legislatures, but it also reinforces the close relationship between heritage and nationhood, patrimonie and patria, which has been explored at length in the academic literature. ${ }^{4}$

Some authors have argued for the value of a more comparative, international framework for the analysis of heritage histories. Swenson, for example, notes how the development of heritage legislation in Europe between approximately 1870 and 1914 constituted an arena both for collaboration and rivalry between nations, while the protection of a nation's monuments became an index of its civilized state. ${ }^{5}$ The transference or 'transplanting' of legislative solutions from one national context to another had long been central to the process of drafting new laws, and the field of heritage law was no exception. To these ends international surveys of legislation were undertaken and disseminated such as that published in a British parliamentary report of 1897 concerning 'the statutory provisions existing in foreign countries for the preservation of historical buildings'. ${ }^{6}$ While the principles of legislative transferability remain matters of debate

\footnotetext{
1 See, for example, Henry Cleere (ed.), Archaeological Heritage Management in the Modern World (London, 1989).

2 Hilary Soderland, 'The History of Heritage: A Method in Analysing Legislative Historiography', in Mary Louise Stig Sørensen and John Carman (eds), Heritage Studies: Methods and Approaches. (Abingdon, 2009), 55-84; Jukka Jokilehto, A History of Architectural Conservation (Oxford, 1999).

${ }^{3}$ For example, John Delafons, Politics and Preservation: A Policy History of the Built Heritage, 1882-1996 (London, 1997); David Harmon, Francis P. MacManamon and Dwight T. Pitcaithley (eds), The Antiquities Act: A Century of American Archaeology and Nature Conservation (Tucson, 2006); Simon Thurley, Men from the Ministry: How Britain Saved its Heritage (New Haven, CT, 2013).

${ }^{4}$ See, for example, David Lowenthal, The Heritage Crusade and the Spoils of History (Cambridge, 1998); Philip L. Kohl, 'Nationalism and Archaeology: On the Constructions of Nations and the Reconstructions of the Remote Past', Annual Review of Anthropology xxvii (1998), 223-46; Anthony D. Smith, 'Authenticity, Antiquity and Archaeology', Nations and Nationalism vii (2001), 441-9; Elazar Barkan and Ronald Bush (eds), Claiming the Stones, Naming the Bones: Cultural Property and the Negotiation of National and Ethnic Identity (Los Angeles, CA, 2002).

${ }^{5}$ Astrid Swenson, 'The Law's Delay? Preservation Legislation in France, Germany and England, 1870-1914', in Melanie Hall (ed.), Towards World Heritage: International Origins of the Preservation Movement 18701930 (Farnham, 2011), 139-54.

${ }^{6}$ Reports from Her Majesty's Representatives Abroad as to the Statutory Provisions Existing in Foreign Countries for the Preservation of Historical Buildings (London, 1897); see Delafons, Politics and Preservation, 27; Swenson, 'The Laws Delay?', 146.
} 
among legal scholars, ${ }^{7}$ through such practices there was a clear diffusion of underlying attitudes and ideologies relating to heritage from one nation to another.

Our objective in this article is to look beyond the national framework to consider circulations of heritage legislation through specifically colonial networks and information flows. These legislative migrations provide insight not only into processes of cultural transfer from one territory to another, but also act as prisms through which we can discern differential attitudes toward the various colonies according to the perceived nature of their heritage. As colonial administrators sought to reconcile or amend models of heritage legislation that emerged in one part of the colonial empire with the realities of the heritage that they encountered in another, they were forced to make decisions that reveal underlying colonial predispositions and prejudices, the legacy of which continues to shape perceptions and, indeed, heritage legislation in the post-colonial world. India thus becomes a land of lost civilizations, East Africa the 'cradle of humankind', West Africa a wellspring of 'primitive art'. Each of these categories of heritage - the monumental, the palaeoanthropological, and the ethnological - were valued differently, but these values also changed over the course of the first half of the twentieth century as the new scientific disciplines of archaeology, palaeontology and anthropology transformed contemporary understandings of the past. This development in heritage value can be tracked both temporally, but also geographically, in the revisions made to heritage legislation as it migrated along various trajectories.

The imperial framework that we employ also challenges the assumption that colonial laws and ordinances migrated centrifugally from the metropolitan core to the colonial periphery. In fact we find that the direction of influence was more complex and multidirectional. It is no coincidence, for example, that Lord Curzon, as Viceroy of India, had first championed the passing of India's 1904 Ancient Monuments Preservation Act, before supporting the Ancient Monuments Consolidation and Amendment Act, which passed into English law in 1913. Here we follow Tilley, ${ }^{8}$ who draws upon a phrase coined by Lord Hailey in his 1938 An African Survey, and argue that the colonial empire constituted not only 'a living laboratory' in the field of scientific knowledge, but was also an arena for legislative experimentation. It is well-known, for example, that Lubbock's ambitious 1873 National Monuments Preservation Bill met with strong opposition from British parliamentarians concerned that it would impinge upon private property rights and was thus rendered 'a relatively toothless measure' during its arduous passage into law. ${ }^{9}$ In India, free from such constraints, a more biting heritage law (Act XX) had already been passed in 1863, and this paved the way for Curzon's notoriously stringent legislation of 1904 , which gave the state the powers of compulsory purchase of protected monuments and made damage to protected monuments a criminal offense. It was this more stringent

\footnotetext{
${ }^{7}$ Helen Xanthaki, 'On Transferability of Legislative Solutions: The Functionality Test' in Constantin Stefanou and Helen Xanthaki (eds), Drafting Legislation: A Modern Approach (Aldershot, 2008), 1-18; David Nelken, 'Towards a Sociology of Legal Adaptation', in David Nelken and Johannes Feest (eds), Adapting Legal Cultures (Oxford 2001), 7-51.

8 Helen Tilley, Africa as a Living Laboratory: Empire, Development, and the Problem of Scientific Knowledge, 1870-1950 (Chicago, IL, 2011).

9 Henry Cleere, 'Great Britain', in Henry Cleere (ed.), Approaches to the Archaeological Heritage

(Cambridge, 1984), 54; Timothy Champion, 'Protecting the Monuments: Archaeological Legislation from the 1882 Act to PPG 16', in Michael Hunter (ed.), Preserving the Past: The Rise of Heritage in Modern Britain (Stroud, 1996), 38-9.
} 
Indian law that provided the model for the amendment of the English law in 1913, when, as Champion notes, the near unanimous support of parliament - including its support for restrictions on the rights of private owners - 'could not have made a stronger contrast with Lubbock's tribulations'.10

A second objective of this article is to consider the relationship between the protection of 'natural' and 'cultural' heritage in colonial heritage legislation, and particularly the shifting position of what we might regard as 'indigenous' heritage within this provision. The monuments that Curzon so admired in India belonged to a civilization for which the British Empire was considered a worthy successor. In a famous speech to the Asiatic Society of Bengal in 1900, he explained that such monuments 'do not represent an indigenous genius', but 'are exotics imported into this country in the train of conquerors'. ${ }^{11}$ It was the decaying remnants of India's Mughal heritage that Curzon sought to save, while that which awaited discovery 'in the probing of archaic mounds' and 'in the excavation of old Indian cities' as yet remained hidden behind 'a curtain of dark and romantic mystery'. ${ }^{12}$ This curtain was only lifted in 1921-22 with the excavation of Mohenjo-Daro and the discovery of the Bronze Age Indus Valley Civilization. ${ }^{13}$ There was no place, however, in this discursive and legislative conceptualization of heritage as the monumental remains of lost civilizations for the heritage of India's contemporary population. Even as the vernacular heritage of England's rural past was being valorized by organizations such as the National Trust (the first building to be acquired and 'saved for the nation' by the Trust was a modest thatched cottage and not a castle), so the heritage of India's indigenous peoples went unrecognized. In the evolutionist ideology of the time, India's tribal populations were themselves regarded as a living relic of the prehistoric past: a primitive people without history, and therefore without heritage. Being closer to nature than to civilized culture, however, they were also perceived as the innate custodians of the natural environment, and, ironically, their customary laws and traditional practices fell under the protection of India's forestry conservation legislation.

While the relationships between natural and cultural heritage, and between what we now refer to as tangible and intangible heritage, have been differently configured in different territories through these legislative migrations, it is only relatively recently that these false distinctions have been overcome. A significant step in addressing a more holistic understanding of heritage, as well as acknowledging the plurality of coexistent heritage values, was the passing of the Australian Heritage Commission Act of 1975. This Act used the rubric of the 'National Estate' (a term coined by the British architect and conservationist Sir Clough Williams-Ellis in the 1930s) to encompass both Australia's natural and cultural environments, including sites with 'strong or special association with a particular community or cultural group for social, cultural or spiritual reasons'. ${ }^{14}$ This was an acknowledgement of the need to incorporate Aboriginal heritage, including its inseparability from the 'natural' landscape, within the national heritage legislation. The

\footnotetext{
10 Champion, 'Protecting the Monuments', 44.

11 George Nathaniel Curzon, Speeches by Lord Curzon, Viceroy and Governor-General of India. 1898-1901 (Calcutta, 1901), 192; David Gilmour, 'Empire and the East: The Orientalism of Lord Curzon', Asian Affairs xxvi (1995), 270-7.

12 Curzon, Speeches, 193.

13 John H. Marshall, 'First Light on a Long-Forgotten Civilisation: New Discoveries of an Unknown Prehistoric Past in India', Illustrated London News (20 Sep. 1924), 528-32, 548.

14 Australian Heritage Commission Act, 1975 (Commonwealth of Australia).
} 
same concept was incorporated into South Africa's post-Apartheid National Heritage Resources Act of 1999, in which the national estate was expanded to include a very wide range of sites and landscapes with cultural, historical, archaeological and geological significance, as well as movable objects, and 'intangible aspects of inherited culture' such as oral history, ritual, skills and techniques, and indigenous knowledge systems. ${ }^{15}$ Recognizing the potential of heritage to 'affirm our diverse cultures', 'deepen our understanding of society' and 'facilitate healing', these contemporary heritage laws reflect the influence of international policy-shaping agencies such as UNESCO with its standardssetting conventions, declarations and recommendations. Just as UNESCO has been accused of imposing forms of homogeneous 'cultural globalization' onto the non-Western world, ${ }^{16}$ so it might be said that the colonial legislative migrations we are concerned with here were a medium for a kind of proto-globalization of heritage ideology. ${ }^{17}$ The reality, both then and now, is more complex, and despite the reproduction of clauses, often verbatim, from one context to another, the application of the law took very different forms.

\section{Charting the spatio-temporal migrations of cultural heritage legislation}

\section{Let us now turn to look more closely at the processes through which British colonial} heritage legislation was drafted by considering a number of case examples. The impetus behind the drafting and revision of new legislation was often provoked by particular incidents that came to the attention of colonial governments or the Colonial Office itself. The Colonial Office often took a proactive stance, urging colonial governments to take action, and disseminating what it perceived to be relevant examples of heritage legislation from other territories. The correspondence between the colonial administrators and officials in the Colonial Office, as well as with experts invited to comment, provides insight into the perceptions and values of those directly involved in colonial governance. This is relevant not only within the specific field of heritage, but is also telling of more general attitudes towards particular territories. When acts or ordinances successfully passed through the local legislative process, copies were presented to the Colonial Office for approval. These were usually accompanied by a legal report that often contained a comparative table showing what clauses had been incorporated from which precedents, which were adapted, and what had been drafted anew. Lack of space precludes an extensive discussion of each case, but we have selected examples which highlight different issues as well as the more general progress of heritage law across space and time within the British Empire. ${ }^{18}$

\footnotetext{
15 National Heritage Resources Act, 1999 (Republic of South Africa).

16 William S. Logan, 'Globalizing Heritage: World Heritage as a Manifestation of Modernism and Challenges from the Periphery', in David S. Jones (ed.), 20th Century Heritage: Our Recent Cultural Legacy: Proceedings of the Australian ICOMOS National Conference 2001, (Burwood, Vic, 2002), 51-7.

17 Tony Balantyne, 'Empire, Knowledge and Culture: From Proto-Globalization to Modern Globalization', in A.G. Hopkins (ed.), Globalization in World History (London, 2002), 115-40.

18 Since the long history of antiquarianism, museum development, state-sponsored archaeology, and heritage legislation in India has been well charted, we draw our case studies from elsewhere. We shall, however return to India in our discussion of forestry legislation. Regarding the preservation of antiquities in India, see Dilip K. Chakrabarti, A History of Indian Archaeology: From the Beginning to 1947 (New Delhi, 1988); Tapati Guha-Thakurta, Monuments, Objects, Histories: Institutions of Art in Colonial and Postcolonial India (New York, 2004); Indra Sengupta, 'A Conservation Code for the Colony: John Marshall's Conservation Manual and Monument Preservation Between India and Europe', in M. Falser and M. Juneja (eds.),
} 


\section{Southern Rhodesia 1902, Cyprus 1905}

It is important to stress that there was no single point of origin from which heritage legislation diffused through British colonial networks. Heritage legislation was often introduced in response to highly specific circumstances and followed distinct trajectories, albeit with interesting intersections and points of confluence. While such legislative migrations reveal much about colonial power relations, they also impart the complexity of these relations, not least demonstrating that there were very different views within the colonial administration regarding the significance of a region's heritage and whose interests should be prioritized in the measures proposed. The Ancient Monuments Protection Ordinance that was passed by the Legislative Council of Southern Rhodesia in 1902, for example, marks a change in attitudes whereby the region's remarkable ruins were no longer regarded as repositories of ancient gold to be 'plundered for profit' by licenced prospectors, ${ }^{19}$ but became sites of conjecture and mystery, which fired the popular imagination and began to attract tourists from among the territory's white settlers. ${ }^{20}$ In Cyprus, by way of contrast, scholarly interest in the island's archaeological heritage was never in doubt. When, in 1896, the Cyprian Legislative Council proposed to strengthen regulations relating to the excavation and export of antiquities, however, the British Museum - which was then leading an archaeological expedition on the island claimed that the restrictions would be 'inconvenient' and lobbied the Colonial Office to veto the bill. ${ }^{21}$ There followed a protracted debate, in which the British authorities in Cyprus generally supported the local community's wishes to stop the large scale export of artefacts. It would take nine years for the matter to be settled with the passing of the 1905 Antiquities Law, and even then this proved to be effective only temporarily.

The territory occupied by Cecil Rhodes' British South Africa Company (BSAC), which eventually became Southern Rhodesia and later Zimbabwe, was acquired for the explicit purpose of exploiting its mineral resources. ${ }^{22}$ The region was also remarkable for the large number of monumental ruins, most notably the massive stone complex of Great Zimbabwe, which European explorers and adventurers encountered there from the 1870s, and which eventually gave its name to the postcolonial nation. As Garlake notes, 'probably no other prehistoric site has given rise to such strong, widespread and often bizarre emotional responses'. ${ }^{23}$ Grounded in racist conceptualizations of African primitivism, the so-called 'Zimbabwe controversy' centred around assertions that the builders of these monumental remains could not possibly be indigenous to the region, but must have their origins in the ancient civilizations of the Mediterranean or Middle East. In particular the speculation of the sixteenth-century Portuguese missionary João dos Santos associating

Archaeologizing Heritage? Transcultural Entanglements between Local Social Practices and Global Virtual Realities (Heidelberg, 2013), 21-37.

${ }^{19}$ Henrika Kuklick, 'Contested Monuments: The Politics of Archaeology in Southern Africa', in George W. Stocking (ed.), Colonial Situations: Essays on the Contextualization of Ethnographic Knowledge (Madison, WI, 1991), 142.

20 Peter S. Garlake, Great Zimbabwe (London, 1973).

${ }^{21}$ Memorandum regarding the Preservation of Antiquities, 21 Feb. 1905 (Cyprus 6994/1905): The National Archives, London (hereafter TNA), CO 67/142.

22 Kuklick, 'Contested Monuments', 138.

${ }^{23}$ Garlake, Great Zimbabwe, 12. 
the ruins with the gold mines of the Biblical Ophir fired the imagination of prospectors and amateur archaeologists alike. Thus it was that BSAC granted concessions to concerns such as Rhodesia Ancient Ruins Ltd to mine the ruins for the treasure they were believed to conceal. This company was given rights to 'explore and work for treasure' in 'all ancient ruins south of the Zambezi', with the exception of Great Zimbabwe. ${ }^{24}$ In return BSAC would receive 20 percent of the prospectors' finds and Rhodes himself, who was an avid collector, would have the first right to purchase any discoveries. ${ }^{25}$ In the five years between 1895 and 1900 that it operated, Rhodesia Ancient Ruins Ltd recovered less than 900 ounces of gold, but the destruction caused by their digging, and that of other concessions, was immense. ${ }^{26}$

Given that these prospecting activities were conducted under permit, the 1902 Ancient Monuments Protection Ordinance was evidently not only motivated by a desire to combat unlawful damage being done to Southern Rhodesia's antiquities. The ordinance was passed at a time of transition of administrative power from the commercially-driven BSAC to the South Africa High Commission, and reflected changing perceptions of the significance of these monumental ruins, which had by then begun to attract considerable international attention. The extent of the damage already done to the ruins was also becoming apparent and was attracting considerable criticism. ${ }^{27}$ The new Monuments Ordinance vested control of Southern Rhodesia's antiquities in the figure of the Administrator (the head of the Southern Rhodesian government at the time). The Administrator's Office was thus given responsibility for considering applications and granting permits for archaeological excavation work, and it became a legal requirement that all archaeological finds had to be reported to this office. Failure to comply could result in prosecution.

Ironically it was none other than Richard Nicklin Hall, a journalist turned amateur archaeologist, who had worked with Rhodesia Ancient Ruins Ltd, who was appointed Curator of Great Zimbabwe at this time. While Hall's responsibilities were limited to preserving the ruins in order to make them more attractive to tourists, he disregarded this and undertook a large amount of highly destructive excavation work. Hall justified his actions in the name of 'preservation', claiming that he was merely removing 'the filth and decadence of the Kaffir occupation' with the intention presumably of the revealing the remains of the ancient builders. ${ }^{28}$ In so doing he made the subsequent stratigraphical reading of the site impossible. Hall's activities were condemned as 'reckless blundering' by David Randall-Maclver, the first trained archaeologist to investigate Great Zimbabwe, and Hall was duly dismissed. Randall-Maclver's excavations in 1905 disproved the speculations of Hall and other amateur diggers. He dated the ruins to a more recent period and found no evidence to suggest that the structures had been built by anyone other than the indigenous people of the region.

Whether this evidence of a sophisticated, indigenous urban society in Southern Africa succeeded in dispelling ingrained attitudes regarding the primitive state of the

\footnotetext{
${ }^{24}$ Garlake, Great Zimbabwe, 70; William H. Stiebing, Uncovering the Past: A History of Archaeology (Oxford, 1993), 222.

25 Garlake, Great Zimbabwe, 70.

26 Ibid.

${ }^{27}$ E.E. Burke, 'Archives and Archaeology', Rhodesiana xvii (1967), 68.

${ }^{28}$ Garlake, Great Zimbabwe, 72.
} 
region's local population is doubtful, and indeed the controversies did not end ${ }^{29}$ It is interesting to note, however, that in 1912 the Ancient Monuments Protection Ordinance was complemented by the passing of the Bushmen Relics Protection Ordinance. Whereas the earlier Ordinance had nominally protected monuments and relics predating 1800, it made no provision for the protection of rock art sites, which continued to be damaged through mining activity. ${ }^{30}$ The Bushmen Relics Ordinance addressed this anomaly, such that it became illegal to remove, without permission, 'any drawing or painting on stone or petroglyph of the kind ... believed to have been executed by the South African Bushmen or other aboriginals'. The Bushmen Relics Ordinance also brought Southern Rhodesian legislation in line with that of the newly created Union of South Africa, which had passed an identical act the previous year. As Nick Shepherd has argued this legislation contributed to the emergence of a particular discourse around the indigenous peoples of southern Africa, involving a slippage between the emergent disciplines of archaeology and ethnology, whereby the 'Bushmen' or 'San' became regarded as a 'remnant race or evolutionary "hold over"' - a living Palaeolithic people. ${ }^{31}$

Whereas the very presence of monumental stone ruins in Southern Rhodesia was challenging to European conceptualizations of sub-Saharan Africa and thus proved controversial, the situation in Cyprus was very different. As the archaeologist, Reginald Poole wrote in 1878, the year in which the island became a British Protectorate, 'the mineral wealth of Cyprus may be uncertain, but there can be no doubt of its archaeological riches' ${ }^{32}$ In the years immediately prior to the signing of the Cyprus Convention, through which the administration of Cyprus was passed to Britain in return for the pledge of military support for Turkey against Russia, the looting of antiquities had become widespread, not least not satisfy the antiquarian passions of foreign consuls and officials. The most notorious case was that of the American consul, General Luigi Palma di Cesnola, whose 'large scale plundering expeditions netted more than 10,000 items, most of which were exported from the island after 1870 and purchased by the Metropolitan Museum in New York'. ${ }^{33}$ When the British assumed control of Cyprus, an existing Ottoman antiquities law, passed in 1874, was enforced more strictly and a ban was imposed on unauthorized excavation. The British High Commissioner resolved to provide permits only to archaeologists associated with accredited scientific bodies; this favoured British expeditions led by institutions such as the Cyprus Exploration Fund (1887-94) and British Museum (1893-99). ${ }^{34}$

Under the Ottoman law, finds from excavations for which a permit had been granted were to be divided three ways: a third to the Government, a third to the excavator, and a third to the owner of the land being excavated. This led to unscrupulous archaeologists

\footnotetext{
${ }^{29}$ See Joost Fontein, The Silence of Great Zimbabwe: Contested Landscapes and the Power of Heritage (London, 2006).

30 Webber Ndoro and Gilbert Pwiti, 'Heritage Management in Southern Africa: Local, National and International Discourse', Public Archaeology ii (2001), 29.

${ }_{31}$ Nick Shepherd, 'State of the Discipline: Science, Culture and Identity in South African Archaeology', Journal of Southern African Studies xxix (2003), 823-44.

32 R.S. Poole, 'Cyprus: Its Present and Future', The Contemporary Review xxxiii (1878), 135-54.

${ }^{33}$ A. Bernard Knapp and Sophia Antoniadou, 'Archaeology, Politics and the Cultural Heritage of Cyprus', in Lynn Meskell (ed.), Archaeology Under Fire: Nationalism, Politics and Heritage in the Eastern Mediterranean and Middle East (London, 1998), 29-30.

${ }^{34}$ A. Bernard Knapp, The Archaeology of Cyprus: From Earliest Prehistory through the Bronze Age (Cambridge, 2013), 20.
} 
purchasing the land to be excavated and thus acquiring the right to two thirds of the finds. ${ }^{35}$ The Ottoman law also proved to be liberal with regard to the export of antiquities. Together with calls to establish the Cyprus Museum on a better footing, this led to the drafting of two new pieces of legislation - a museum law and an antiquities law - which were passed by the Legislative Council in 1896. The intention was to give the Cyprus Museum the financial and legal wherewithal to house antiquities recovered in excavation such that they 'should belong absolutely to the Museum, in trust for the Cyprus community'. ${ }^{36}$ Under the proposed new antiquities law, a clause stipulated 'that no object of antiquity shall be exported unless a similar object is already in possession of the Museum'. ${ }^{37}$ In a 1905 Colonial Office memorandum summarizing what would turn out to be a protracted debate, it is noted that the British Museum 'got wind' of this clause and its Director, Sir E. Maunde Thompson, wrote to say that this was a serious matter and 'the Trustees of the British Museum would find it very inconvenient'. ${ }^{38}$ The British Museum was then undertaking excavations at the Late Bronze Age site of Enkomi and, in Thompson's words, had 'just hit upon a most important series of tombs containing antiquities of great interest and value'. ${ }^{39}$ He expressed a hope that the new law would be vetoed by the Colonial Office so that the British Museum would be less constrained with regard to the export of objects that were being discovered. The Colonial Office effectively complied.

An argument was made that the inclusion of the offending clause 'would probably put an end to the search for antiquities in Cyprus', and the High Commissioner was directed to prepare revised versions of the laws. These were again submitted to the British Museum for comment, and again objections were raised. The matter was not easily resolved and over the following eight years there was considerable correspondence between the various parties. During this time, the Colonial Office obtained and sent copies of antiquities laws from Greece (1899) and Italy (1902), which were felt to be 'applicable in principle in Cyprus'. ${ }^{40}$ Relevant sections were incorporated into revisions of the new Cyprus law, which now included provision for both the protection of antiquities and for the financing and management of museums. Still, however, the British Museum insisted in the inclusion of a clause that would permit the High Commissioner, with the sanction of the Secretary of State for the Colonies, to allow 'authorized excavations by learned Societies' to retain and export up to two thirds of the antiquities discovered. ${ }^{41}$ It is to the credit of Sir Charles King-Harman, who became High Commissioner to Cyprus in 1904, that he supported the position of the local members of the Legislative Council and resisted the edicts of the Colonial Office. In a despatch to the Secretary of State for the Colonies in February 1905 he reported on the earnestness of the desire of Cypriots 'to preserve the antiquities found in their soil' and that the Legislative Council would not accept what was referred to as the 'British Museum clause' of the Antiquities Bill. In a robust defence of the Cypriot position, King-Harman added that the learned societies 'have in time past made

\footnotetext{
35 Memorandum of the King's Advocate on the Law of Antiquities in Cyprus, 3 Mar. 1904 (Cyprus 8922/1904), TNA, CO 67/138.

36 Memorandum, 21 Feb. 1905, TNA, CO 67/142.

37 Ibid.

38 Ibid.

39 Ibid.

40 Despatch from C. King Harman, High Commissioner of Cyprus, to the Secretary of State for the Colonies regarding the Preservation of Antiquities, 21 Feb. 1905 (Cyprus 6994/1905), TNA, CO 67/142.

${ }^{41}$ Memorandum, 21 Feb. 1905, TNA, CO 67/142.
} 
such plentiful harvest from the Cyprus antiquities' and that he had little sympathy with their claim that they should be exempted from export control. ${ }^{42}$ At last, the Colonial Office conceded, the troublesome clause was removed, and in April 1905 King-Harmon wrote to the Secretary of State for the Colonies advising that the Bill had passed into law. ${ }^{43}$

The Cyprus Museum eventually reopened in a new porticoed building in 1909 and its collections grew as a result of the 1905 law, which restricted all exports of antiquities from the island. There was a continuing concern, however, that these restrictions would make Cyprus a less attractive destination for foreign archaeologists. ${ }^{44}$ Indeed, the colonial authorities in Cyprus came under increasing pressure from overseas archaeological missions to grant them exemption from the law and export objects unearthed during their research. Finally, in 1927, the Swedish Cyprus Expedition, led by Einar Gjerstad, successfully lobbied for an amendment to the law, which allowed them to remove $65 \%$ of their finds to Sweden. ${ }^{45}$ A 1931 photograph of hundreds of crates of archaeological objects on the docks at Famagusta awaiting shipment to Stockholm provides a sobering reminder of the scale on which antiquities were permitted to leave Cyprus at this time. ${ }^{46}$ On the other hand, as Bounia and Stylianou-Lambert argue, the expedition also provided valuable material from the Neolithic through to the Roman period, which enriched the Cyprus Museum and added immeasurably to the understanding of the island's heritage. ${ }^{47}$

By the mid-1930s, in both Cyprus and Southern Rhodesia, these early legislative experiments had been swept away by the passing of new heritage laws. Ironically, it was a later Director of the British Museum, George Hill, who was largely responsible for drafting the 1935 Antiquities Law in Cyprus. (He had earlier redrafted the antiquities laws for Iraq and Palestine. $)^{48}$ With the enactment of this more stringent law, a new professional Department of Antiquities was established, and the Cyprus Museum became properly nationalized insofar as it was fully funded by the State. ${ }^{49}$ At the same time, a new 'British Museum clause' was included, which gave the British Museum first refusal to purchase any antiquities that the Director of Antiquities decided not to retain in the national collection. ${ }^{50}$ The Southern Rhodesian Monuments and Relics Act of 1936 also brought into being a new body, the Commission for the Preservation of Natural and Historical Monuments and Relics, which - as the name would suggest - was responsible not only for safeguarding ancient monuments and archaeological objects, but also for protecting areas of land that were of interest for archaeological, historical, scenic or geological reasons, or indeed due to their distinctive flora or fauna. ${ }^{51}$ As we will see in the case of British West

\footnotetext{
42 Despatch from C. King Harman, 21 Feb. 1905, TNA, CO 67/142.

43 Despatch from C. King Harman, High Commissioner of Cyprus, to the Secretary of State for the Colonies regarding the Preservation of Antiquities, 19 Apr. 1905 (Cyprus 14212/1905), TNA, CO 67/142.

44 Alexandra Bounia and Theopisti Stylianou-Lambert, 'National Museums in Cyprus: A Story of Heritage and Conflict', in Peter Aronsson and Gabriella Elgenius (eds), European National Museums: Identity Politics, the Uses of the Past and the European Citizen (Linköping, 2011), 178.

45 lbid.

46 Knapp, Archaeology of Cyprus, 21.

47 Bounia and Stylianou-Lambert, 'National Museums in Cyprus', 178.

48 Ana Filipa Vrdoljak, International Law, Museums and the Return of Cultural Objects (Cambridge, 2006), 86.

49 Ibid.; Bounia and Stylianou-Lambert, 'National Museums in Cyprus', 178.

50 Antiquities Law, 1935 (Cyprus).

51 Monuments and Relics Act, 1936 (Southern Rhodesia).
} 
Africa, both of these laws were regarded as exemplars and were distributed widely through colonial circuits.

\section{Kenya 1927, Uganda 1934}

By the 1920s archaeology was becoming established as a more scientifically rigorous discipline and this would have a significant impact on the development of heritage legislation, which, as we have seen, in the colonial context had hitherto been focused on monumental structures and classical antiquity. In Africa, some of the most remarkable discoveries of the inter-war period were in the new field of palaeoanthropology. These were changing our understanding of human evolution, and through the celebrated work of Raymond Dart in southern Africa and Louis Leakey in East Africa, Africa soon became regarded as the 'cradle of humankind'. Despite coming three years after Dart's discovery of 'Taung Child' and coinciding with Leakey's first excavations in the Rift Valley, Kenya's 1927 Ancient Monuments Preservation Ordinance was, however, considerably out of step with these developments and was itself something of a 'hold-over' from another time and another place. Save from the deletion of those clauses relating to the traffic in antiquities, the Ordinance was copied almost verbatim from India's Ancient Monuments Preservation Act of 1904. Indeed, a memorandum appended to the Bill that was presented before Kenya's Legislative Council acknowledges this fact and further notes that the Indian legislation 'was the late Marquess Curzon's especial care and it has already abundantly justified its enactment in India'. ${ }^{52}$ Curzon had died in 1925, and Thomas Hart goes so far as to argue that the Kenyan legislation was passed in his honour - Sir Edward Grigg, Governor of Kenya, and others in the Kenyan colonial administration having close associations with the Indian Civil Service. ${ }^{53}$

A legal report, sent with the final version of the Kenyan Ordinance to the Secretary of State for the Colonies in November 1927, provides further information concerning the rationale for introducing the legislation. Here it is stated that the issue was first taken up in 1924 when the colonial government of Kenya invited its administrative officers to make suggestions for the 'preservation and identification of such memorials as the graves of early explorers, officials and pioneers, old Government stations and evidence of earlier civilisations'. ${ }^{54}$ While not excluding indigenous sites, it is clear that the primary interest was in preserving the more visible material remains of Kenya's colonial history, as well as its history of cultural contact with Arabian and Portuguese traders and settlers. This is evident, for example, in the province-by-province list of monuments that might be eligible for protection under the legislation that was published in the Official Gazette in June $1927 .{ }^{55}$ The majority of the sites listed in the interior of the Protectorate are the graves of British pioneer settlers, whilst the ruined towns and forts of Coast Province - identified as being Portuguese, Arab and Persian in origin - dominate the list as a whole. Forgetful of

\footnotetext{
52 A Bill to Provide for the Preservation of Ancient Monuments and Objects of Archaeological, Historical or Artistic Interest, 1927 (Kenya), TNA, CO 533/372/14.

53 Thomas G. Hart, 'Gazetting and Historic Preservation in Kenya', CRM: The Journal of Heritage Stewardship iv (2007).

54 Legal Report, The Ancient Monuments Preservation Bill, 1927, 21 Oct. 1927 (Kenya X.10524/1927), TNA, CO 533/372/14.

55 The Official Gazette of the Colony and Protectorate of Kenya xxix (7 Jun. 1927), 687-92.
} 
the less monumental heritage of Kenya's various 'indigenous' ethnic groups, on the occasion of the second reading of the Bill before the Legislative Council, the Colonial Secretary, Sir Edward Denham, remarked that 'We are inclined to talk so much of Kenya as the youngest Colony in the British Empire ... that we are perhaps apt to be forgetful of the fact that other civilizations reached this coast and left their mark upon it'. ${ }^{56}$

The limitations of Kenya's 1927 Ordinance would come to light as a consequence of palaeoanthropological discoveries by Leakey and others in the fossil beds of the region in the later 1920s and early 1930s. Whereas the Southern Rhodesia and Cyprus laws had introduced measures to regulate the excavation of archaeological sites and control the export of finds, this was inadequately addressed in the Indian legislation on which the Kenyan Ordinance was based and which was concerned chiefly with protecting India's architectural heritage. As the significance of East Africa's archaeological and palaeological record became known, so there was increasing pressure to safeguard it from the kinds of reckless excavation that had befallen Great Zimbabwe. This led, for example, to the passing of the Preservation of Archaeological Objects Ordinance in neighbouring Tanganyika in $1929 .{ }^{57}$ The amendment of Kenya's heritage legislation and introduction of similar legislation in Uganda in 1934 was not, however, driven by purely scientific interests, but also by international politics and rivalry: not least rising tensions between Britain and Italy in relation to Mussolini's expansionist interests in Abyssinia/Ethiopia.

This animosity was expressed forcefully in relation to a year-long expedition being led by Nino del Grande of the Fascist Colonial Institute in Rome. ${ }^{58}$ The expedition's proposed itinerary included the British territories of Kenya, Uganda and Sudan, where it was intended that 'anthropological and paleontological excavations and research' would be undertaken. The lead palaeoanthropologist on the expedition was Raymond Dart, whose work had at that time been discredited, not least by Leakey, who was then regarded as the major authority on the subject. The issue was referred to the British Foreign Office, which in turn sought the advice of the British Museum, the Natural History Museum and the Royal Society. Each in turn raised concerns about the credentials of the expedition members, stressing the need for careful scientific methods in palaeontological excavation, drawing attention to existing research being conducted by British institutions, and arguing that palaeontological material collected on British territory 'should be placed in the National Collection for preservation and study' and not allowed to fall into foreign hands. These responses were forwarded to the Italian Chargé d'Affaires in London and communicated to the governors of Kenya and Uganda. The letter to the Italian authorities makes it clear that while the expedition would not be stopped from entering Kenya and Uganda, 'it is almost certain that they will not be permitted to engage in any work involving excavation'. 59

In fact, as noted above, the legal grounds for restricting excavation of sites other than those declared as ancient monuments in Kenya was very limited, and no heritage

\footnotetext{
${ }^{56}$ Colony and Protectorate of Kenya, Legislative Council Debates, September 13, 14, 15 and 16, 1927, 327 328, TNA, CO 533/372/14.

57 Leakey's first expedition to Olduvai Gorge in Tanganyika took place in 1931. This would become one of the most significant palaeoanthropological sites in the world.

58 See Original Correspondence regarding Italian Expedition to Central Africa (East Africa 4010/1933), TNA, CO 822/91/16.

59 Ibid.
} 
legislation existed in Uganda at all. That Uganda's 1934 'Ordinance to provide for the Preservation of objects of Archaeological and Palaeontological interest' was swiftly passed through the legislature as a response to this threat is acknowledged in a Colonial Office memorandum:

This Ordinance has been enacted as a result of [a despatch] in which we suggested that permission to engage in archaeological work involving excavations should be withheld from an expedition under the leadership of Signor Nino Del Grande. Apparently there was no legislation in Uganda by which such work could be prohibited. ${ }^{60}$

The memorandum also notes that the Colonial Office sent copies of 'the corresponding legislation in Kenya, Tanganyika and Cyprus' as models from which to draft the Ugandan law. The process through which clauses from these precedents was incorporated into the new Ugandan Ordinance is made particularly clear in the legal report and comparative table that accompanied the final version of the Ordinance submitted to the Colonial Office for approval (Figure 1). Here it is stated that Tanganyika's 1929 Ordinance 'has been taken as the main guide', providing five of its eight sections, with modifications noted. One section has been taken from Kenya's 1927 Ordinance, and another from the Cyprus Antiquities Law of $1905 .{ }^{61}$

In contrast to the more elaborate pieces of legislation introduced in India and Cyprus, Uganda's new law was a mere two pages long. 'A lengthy Ordinance was not required', it is stated in the legal report. In the Colonial Office deliberations before approving the Ordinance, concern is expressed about the appropriateness of the clause adapted from the Cyprus law that any person who discovers an object of archaeological or palaeontological interest is legally obliged to deliver it to the authorities or else risk prosecution. It was felt that this was 'all right for Cyprus where any man may at any time dig up a valuable antique relic but the Uganda native is not in the same box and this section might lead such a person into an innocent breach of the law if he dug up a fossil and did not report it'. The 'native population', the Colonial Office official remarked, 'could not be expected to understand the Ordinance' and it would therefore need to be used with discretion. 'The law will deal with the European digger who is the important person to get at'. 62

\section{Gold Coast 1945, Nigeria 1953}

What begins to emerge as one follows the introduction and amendment of heritage legislation in these different colonial territories is a gradual transformation of perceptions and attitudes: perceptions of the territories themselves as places that even possess a past, and, if this is recognized, attitudes regarding what aspects of the past are valued and

\footnotetext{
60 Memorandum regarding the Preservation of Archaeological Objects Ordinance, 1934, 28 Mar. 1934 (Uganda 23563/1934), TNA, CO 536/181/14.

61 Report on an Ordinance entitled 'The Preservation of Archaeological Objects Ordinance, 1934 ', 9 Feb. 1934 (Uganda 23563/1934), TNA, CO 536/181/14.

62 Memoranda regarding the Preservation of Archaeological Objects Ordinance, 1934, 20 Apr. and 25 May 1934 (Uganda 23563/1934), TNA, CO 536/181/14.
} 
perceived to be threatened and in need of protection. Thus, what starts in India as an orientalist appreciation of Mughal imperial architecture translates into a wider valorization of a monumental heritage: whether of the controversial ruins of Great Zimbabwe or the fortresses and mosques of the East African coast. With the development of the disciplines of archaeology and palaeoanthropology, attention turned to the less visible, but more distant past and concern shifted to controlling both the scientific quality of excavation, crucial to the dating and sequencing of the material record, as well as the distribution of excavated materials. Thus in the 1920s and 1930s, archaeological discoveries led to places such as the Indus Valley being identified as 'cradles of civilization', while palaeoanthropological discoveries in southern and later eastern Africa resulted in these regions becoming celebrated as the 'cradles of humankind'. It is telling that this time, no heritage legislation was deemed necessary in West Africa, which was regarded as being devoid of archaeological or palaeoanthropological interest and was instead fully the domain of the ethnologist.

The situation in British West Africa was to change in 1938 with the discovery of a remarkable cache of 17 cast brass and bronze heads during the digging of house foundations at Ife in Nigeria. ${ }^{63}$ The bronzes would subsequently be dated to the 14th and 15 th centuries and, from the very beginning, they were recognized as examples of the very finest artistic achievement, yet again challenging tenacious perceptions of African - and, in particular, West African - primitivism. ${ }^{64}$ The find was soon brought to international public attention through an article published in the Illustrated London News by a young American anthropologist named William Bascom, who was conducting ethnographic research in the region. ${ }^{65}$ Concerns that the bronzes would be smuggled out of Nigeria and find their way onto the international art market were raised by E.H. Duckworth and Kenneth Murray of the Nigerian Education Department, both of whom had long advocated the value of Nigerian art traditions and argued for the need for museums in the colony. Using their contacts in the London art world, they successfully lobbied the Colonial Office to press the Nigerian Government into taking action. ${ }^{66}$

Despite the passing of an Order in Council prohibiting the export of 'antique African sculptural works of art' from Nigeria in January 1939, it became apparent that a number of the bronze heads had indeed been removed from the country. Two had been purchased by Bascom himself and taken to the USA, and a third was in the hands of a journalist

\footnotetext{
63 For a more extensive discussion of the development of West African heritage legislation and museums see Paul Basu, 'A Museum for Sierra Leone? Amateur Enthusiasms and Colonial Museum Policy in British West Africa', in Sarah Longair and John MacAleer (eds), Curating Empire: Museums and the British Imperial Experience (Manchester, 2013), 145-67.

64 It is worth noting that the reception in Europe of the remarkable hoard of 'ancient bronzes' looted from Benin City 40 years earlier was considerably more ambiguous. While some recognized them as 'treasures', for others they represented the barbarism of a 'degraded race of savages'. Perceptions of the Benin Bronzes changed significantly over the following decades, culminating in their display as part of the 'African Negro Art' exhibition at the Museum of Modern Art in New York in 1935. Needless to say the preservation of Benin's cultural heritage in situ was not a concern of the British expeditionary forces that sacked the Royal Palace in 1897. See Annie E. Coombes, Reinventing Africa: Museums, Material Culture and Popular Imagination (New Haven, CT, 1994), 7-28; Karthryn Wysocki Gunsch, 'Art and/or Ethnographica? The Reception of Benin Works from 1897-1935', African Arts xlvi (2013), 22-31.

65 William Bascom, 'The Legacy of an Unknown Nigerian “Donatello"', Illustrated London News (8 Apr. 1939), 592-4.

66 See Original Correspondence regarding the Preservation of Negro Art (Nigeria 30384/1938), TNA, CO $583 / 234 / 13$.
} 
named H.M. Bate, who later claimed that he was selling it on behalf of a German friend. ${ }^{67}$ Other examples were rumoured to be on the market in Germany. Again at the prompting of Duckworth and Murray, a delegation including John Rothstein, Kenneth Clark and Julian Huxley visited the Colonial Office to lobby for the passing of more stringent legislation to protect antiquities and other artworks in Nigeria. As a result of this meeting, the Secretary of State for the Colonies, Malcolm MacDonald, sent a despatch to each of the governors of Nigeria, Gold Coast and Sierra Leone recommending that legislation be enacted to protect what he described as 'the products of Tropical African culture, especially antiquities'. In an initial draft of the despatch, dated 30 May 1939, it seems that the original intention was to enclose antiquities legislation from Ceylon, Cyprus, Malta and Palestine as models. ${ }^{68}$ In the event, however, it was decided to send only the 1936 Southern Rhodesian Monuments and Relics Act and the 1935 Cyprus Antiquities Law. MacDonald adds a note qualifying the use of these precedents:

As will be seen, these Ordinances envisage a more elaborate form of procedure than is likely to be appropriate in the case of West African Governments and are designed to deal with social conditions and a range of objects which are, in many respects, materially different from those of West Africa. The fundamental object, however, is the same, namely to exercise government control over the exportation of objects of historical or cultural interest, to secure for the Government itself the means of acquiring, under appropriate conditions, such objects as may be thought desirable, to prevent the wilful injury to such objects and also to ensure, so far as possible, that any excavation of sites of archaeological interest is undertaken only by persons properly qualified to conduct such operations. ${ }^{69}$

This pressure from the Colonial Office seems to have had little impact on the colonial governments in West Africa and, with the outbreak of war in September 1939, the process soon stalled. It was not until 1945, with renewed interest in the development of research institutes, universities and museums in West Africa, that the issue of heritage legislation was again raised. Of Britain's West African colonies, it was the Gold Coast that was first to enact an 'Ordinance to provide for the preservation of monuments, relics and objects of archaeological, ethnographical or historical interest' in $1945 .{ }^{70}$ The comparative table included in the Acting Attorney-General's legal report shows that the Ordinance was largely drawn from the Southern Rhodesia Monuments and Relics Act of 1936 (Figure 2). There were, however, some notable changes. There was no provision, for example, for the protection of land valued for its scenic value, or which contained distinctive geological formations, or rare flora or fauna. Perhaps most significant, however, was the inclusion of the protection of 'ethnographic articles', which did not need to be of particular antiquity and

\footnotetext{
67 See Original Correspondence regarding the Preservation of Products of Tropical African Culture (West Africa 33620/1939), TNA, CO 554/121/8. The bronze head that Bate was offering for sale was subsequently purchased by the British Museum (Af1939,34.1).

${ }^{68}$ Draft despatch from the Secretary of State for the Colonies to the Governors of Nigeria, Gold Coast and Sierra Leone regarding the Preservation of Products of Tropical African Culture, 30 May 1939 (West Africa 33620/1939), TNA, CO 554/121/8.

69 lbid.

70 See Original Correspondence regarding Archaeology and Ethnology, Gold Coast (Research 28040/11/1946), TNA, CO 927/31/6.
} 
may include 'objects of ordinary use'. ${ }^{71}$ Like the Southern Rhodesian model, the Ordinance provided for the establishment of a Monuments and Relics Commission. No provision was made, however, for the funding of the Commission's activities, for the preservation of monuments and relics, or for the establishment of museums. The Gold Coast law provided a model for Sierra Leone's Legislative Council, and an almost identical Monuments and Relics Ordinance was passed there in $1946 .{ }^{72} \mathrm{It}$, too, was broad in its scope, but extremely limited in practical application. These Ordinances, it might be surmised, were merely acts of legislative lip service paid by colonial governments, which ultimately saw little need to devote resources to matters of 'archaeological, ethnographical or historical interest'.

The situation in Nigeria was, however, different. Indeed, given that it was the circumstances in Nigeria that provoked these legislative measures, it is ironic that an equivalent Nigerian law was not passed until the Antiquities Ordinance of 1953. In fact, a Nigerian Antiquities Bill had been drafted in 1940. This was a much more sophisticated piece of legislation largely modelled on the Cyprus Law of 1935, although also incorporating clauses from the Southern Rhodesian Ordinance and widening the definition of an 'antiquity' to include any object 'constructed, shaped, inscribed or executed' in Nigeria prior to British administration. ${ }^{73}$ In 1943, furthermore, an Antiquities Service had been established by the colonial government of Nigeria, with Kenneth Murray appointed Surveyor of Antiquities, and a series of museum developments planned. The eventual passing of the 1953 Antiquities Ordinance thus formalized a system that was already partly in operation. As with the Gold Coast and Sierra Leone, this included the establishment of an Antiquities Commission (which would later become the National Commission for Museums and Monuments). Crucially, however, under the Commission's purview was a properly funded Department that was directly responsible for the 'practical realization' of the Ordinance. Murray duly became the first Director of the Antiquities Department, and under his management was a series of Divisions, responsible, in turn, for Monuments and Architecture; Museums; Archaeology; Ethnography; and Education. ${ }^{74}$ Taking responsibility for the establishment of museums, control of archaeological investigations, declaration and protection of monuments, and control of the movement of antiquities and artworks, Nigeria's 1953 Antiquities Ordinance was perhaps the most comprehensive piece of cultural heritage legislation within the British colonial world - certainly within Africa. This was, however, a testimony to the personal commitment and enthusiasms of Murray, and his successor as Director of Antiquities, Bernard Fagg, rather than an example of enlightened colonial governance.

\section{Forestry legislation and the safeguarding of indigenous cultural heritage}

While debates around the role of the state in relation to cultural heritage moved so interestingly from colony to metropole, metropole to colony, and directly between colonies,

\footnotetext{
71 Legal Report on the Monuments and Relics Ordinance, 1945, 14 Nov. 1945 (Research 28040/11/1946), TNA, CO 927/31/6; Monuments and Relics Ordinance, 1945 (Gold Coast).

72 Monuments and Relics Ordinance, 1946 (Sierra Leone)

73 A Bill entitled An Ordinance to Provide for the Better Preservation of Objects of Aesthetic, Historical,

Archaeological or Scientific Interest, 1940, British Museum, Eth Doc 261.

74 Nwanna Nzewunwa, 'Nigeria', in Henry Cleere (ed.), Approaches to the Archaeological Heritage

(Cambridge, 1984), 101-8.
} 
so a similar legislative migration can be seen in relation to natural heritage - for example, in the movement of forestry legislation, or the development of national parks and wildlife reserves. Here we focus more specifically on the progress of forestry legislation in India and how this influenced forestry legislation in other colonial contexts. In the legislative developments we examine, we find that the debate moves from a primary concern with managing the economic exploitation of forests to the development of ideologies of colonial custodianship. Our interest is, however, particularly to consider how forestry legislation came to encompass a concern for indigenous populations and their 'customary rights', extending the colonial state's custodianship from the land to indigenous rights and practices. Communities' 'knowledge and practices' concerning the natural world are now explicitly identified as 'intangible cultural heritage' in UNESCO's 2003 Convention for the Safeguarding of Intangible Cultural Heritage. While forestry and customary rights were not framed in this vocabulary in the period we examine, we argue that in protecting the 'natural contents of ... Empire' (a term used by Curzon), this legislation also came to protect the intangible cultural heritage of certain indigenous groups. The significance of this will be discussed further in our conclusion.

In the nineteenth century, the destructive impact of uncontrolled natural resource exploitation across the colonial world began to give rise to a sophisticated environmentalist response and demands for intervention. The nature of the response to environmental change differed, sometimes fundamentally, from territory to territory, but there were also common influences, some dominated by metropolitan networks, others brought about by new intercolonial patterns of intellectual and bureaucratic exchange. ${ }^{75}$ It is important to note that while India provided the model for early state forestry legislation, many of the ideas on which it drew originated in other parts of the Empire in fragile island environments. Ideas of finitude, extinction and desiccation, for example, first emerged in the eighteenth century in the context of oceanic islands which suffered devastation as a consequence of what John Richards has described as the 'unending frontier' of colonial resource extraction. ${ }^{76}$ This growing environmental consciousness was motivated by several factors, most importantly the climatic fear that if unregulated deforestation were to continue, droughts and famines would ensue. By the nineteenth century early legislative interventions for conservation on islands such as St. Vincent, Mauritius and St. Helena were to lead the way to the first comprehensive set of forestry regulations in India in the guise of the Indian Forest Acts of 1865 and 1878. As a model for the custodianship of natural heritage, the Indian case provided much of the basis for debates on environmental intervention and conservation that went on in other parts of the British Empire, but as with cultural heritage legislation, this translated into disparate forms of practice.

To explore these debates in natural heritage legislation further, we examine in closer detail a number of legislative interventions and their migrations: the 1865 and 1878 Indian Forest Acts, the 1908 Chotanagpur Tenancy Act, and the 1936 Government of India (Excluded and Partly Excluded Areas) Order. The agenda set by this legislation would

\footnotetext{
75 See Richard Grove and Vinita Damodaran, 'Imperialism, Intellectual Networks, and Environmental Change: Unearthing the Origins and Evolution of Global Environmental History', in Sverker Sörlin and Paul Warde (eds), Nature's End: History and the Environment (London, 2009), 23-49.

76 John F. Richards, The Unending Frontier: An Environmental History of the Early Modern World (Berkeley, CA, 2003).
} 
later culminate, in the post-Independence period, with the protection of scheduled areas and, significantly, scheduled tribes - under the Indian Constitution.

\section{Indian Forest Acts 1865, 1878}

The impetus behind the development of forest reservations have been explored extensively by several historians to date. ${ }^{77}$ Although it was not until 1865 that the formal structure of an Indian Forest Act was established, the environmental debate in which state forestry originated had already been going on in India and elsewhere in the British Empire for many decades. These debates were dominated not only by a production agenda but also, and as importantly, by conservationists and surgeons concerned about the relationships between deforestation, climatic deterioration, disease, agricultural production and aesthetics. ${ }^{78}$ While it has been argued that the Forest Act should be understood primarily as a feature of modern state formation, ${ }^{79}$ this obscures a wider variety of imperial agents and motivations. In fact, it is in the context of a modern state agenda within institutions such as forestry that many discordant voices came to be heard in the nineteenth century. This included not only the assertion of different agendas for forestry in terms of the custodianship of natural environments and their flora and fauna, but also, for example, debates concerning the rights of indigenous communities. This latter concern was increasingly being voiced by district officers on the ground as they witnessed the impact of unregulated forest exploitation on local populations.

The transition from uncontrolled deforestation earlier in the nineteenth century to the ambitious programme of state conservation heralded by the 1865 Indian Forest Act is marked by a succession of campaigns warning of the climatic effects of deforestation, as well as arguing the economic case for sustainable forest management. During the 1850s, for example, prominent lobbyists such as the botanist Joseph Hooker, who had travelled widely in Northern India and Nepal, and John McClelland, a pioneering surgeon with the East India Company and subsequently Superintendent of Forests in Burma, were instrumental in convincing the Governor General, Lord Dalhousie, of the value of wholesale state intervention in the forest sector - much against the wishes of private capital. ${ }^{80}$

Eventually, in 1864, under the direction of Hugh Cleghorn and Dietrich Brandis, an India-wide Imperial Forest Department was established, and a year later the Indian Forest Act was passed. While the 1865 Act stands as the first large scale environmental law to be implemented in the nineteenth century it was hurriedly drafted and was regarded as incomplete in many respects. Indeed, it was soon superseded by the 1878 Forest Act, largely drafted by Brandis. This was much more draconian in nature, giving the state absolute control over forested areas, overriding the existing customary practices and rights

\footnotetext{
77 See, for example, Richard H. Grove, Green Imperialism: Colonial Expansion, Tropical Island Edens and the Origins of Environmentalism (Cambridge, 1995); Greg Barton, Empire Forestry and the Origins of Environmentalism (Cambridge, 2002).

${ }^{78}$ See, for example, Hugh Cleghorn, 'Notulae Botanicae No. 1. On the Sand-binding Plants of the Madras Beach', Madras Journal of Literature and Science xvii (1857), 85-9; Cleghorn, 'Notes on the Vegetation of the Sutlej Valley', Journal of the Agricultural and Horticultural Society of India xiii (1865) 372-91.

${ }^{79}$ K. Sivaramakrishnan, Modern Forests: Statemaking and Environmental Change in Colonial Eastern India (Stanford, CA, 1999).

80 Grove, Green Imperialism, 472.
} 
of indigenous peoples..$^{81}$ By 1880 , around a fifth of India's land mass came under the control of the Forest Department. This vision of conservation clearly evinced imperial sensibilities of custodianship voiced by men such as Lord Dalhousie and, later, even more explicitly, by Lord Curzon, who was responsible for the creation of the Kaziranga Reserve Forest (India's first game park) in 1905. Leading a deputation to the Secretary of State for the Colonies in 1906 to campaign for the strengthening of Game Laws across the Empire, Curzon argued that, while 'we are continually using language which implies that we are the trustees for posterity of the Empire ... we are also trustees for posterity of the natural contents of that Empire'. 82

While legislative debates around the formation of game reserves predominated in Africa, debates around forestry took centre stage in India. As R.S. Troup, the founding director of the Imperial Forestry Institute, noted 'to India belongs the credit of having been the first part of the empire to adopt a rational policy of forest conservation and development'. ${ }^{83}$ Officers trained in the Indian forestry service were frequently posted as advisors elsewhere in the British Empire, applying models developed in India in other colonial territories, and in this was Indian forestry was soon transformed into 'empire forestry' ${ }^{84}$ The Cape Colony was the first to follow India's lead. Here, the Indian foresters J.S. Lister and D.E. Hutchins were sent to assist in the establishment of a Forest Department and implement the Cape Forest Act of 1888. Hutchins had drafted the Act, using the Madras Forest Act of 1882 as his model; this in turn had been modelled on the 1878 Indian Forest Act. As Barton notes, Hutchins was also an important figure in the wider diffusion of forestry legislation, travelling and writing reports on forestry affairs for the colonial authorities in Australia, Cyprus, New Zealand, and in various African territories as well as for the British parliament. ${ }^{85}$

The legislation was seen as sweeping and stringent, but also necessary as local authorities recognized their powerlessness to enforce the preservation of forests using existing laws ${ }^{86}$ Over the coming years versions of the Cape's forestry regulations were adopted in the southern African colonies of Orange River Colony (1903), Natal (1903) and Transvaal (1908). Other African territories in which forestry legislation was enacted prior to 1910 included Southern Nigeria (1901), Lagos (1902), and East Africa $(1902,1905) .{ }^{87}$ Each was ultimately grounded in the Indian legislation, though sometimes several steps removed. The East Africa Forestry Regulations were, for example, modelled on the South African legislation, which, as we have noted, was based on the Madras Act of 1888, which was an amendment of the Indian Forest Act of 1878. In each case a forestry department was created, often under the leadership of Indian foresters. In Southern Nigeria, for example, the department was led by H.N. Thompson, who had previously served as

\footnotetext{
${ }^{81}$ Ramachandra Guha, 'An Early Environmentalist Debate: The Making of the 1878 Forest Act', Indian Economic and Social History Review xxvii (1990), 65-84.

82 'Minutes of Proceedings at a Deputation from the Society for the Preservation of the Wild Fauna of the Empire to the Right Hon. The Earl of Elgin, His Majesty's Secretary of State for the Colonies, June 15, 1906', Journal of the Society for the Preservation of the Wild Fauna of the Empire, iii (1907), 24.

83 Robert S. Troup, Colonial Forest Administration (Oxford, 1940), 6.

${ }^{84}$ Barton, Empire Forestry, 102.

85 lbid. 8.

86 lbid.

87 Forest Ordinance, 1901 (Southern Nigeria); Forest Ordinance, 1902 (Lagos); East Africa Forestry Regulations, 28 Jul. 1902, TNA, FO 881/7766.
} 
Assistant Conservator of Forests in Burma. As Conservator of Forests in Southern Nigeria, Thompson was commissioned to undertake a detailed study of forestry in the Gold Coast, and he recommended that the Southern Nigerian Ordinance be amended and applied there. ${ }^{88}$ In other cases, a younger generation of foresters was trained by the Indian officers: Charles Lane Poole, for example, was recruited into the Cape Forestry Department by Hutchins, before being posted to Transvaal, and then to Sierra Leone, where he was responsible for drafting its Forestry Ordinance in 1910. He would later serve in Western Australia, where he drafted the Forests Act of 1918, and he took a prominent part in the first British Empire Forestry Conference in London in 1920.89

While the influence of the 1865 and 1878 Indian Forest Acts can be seen in these legislative migrations, bound up as they were with the physical mobility of forestry experts in the Indian Civil Service and Colonial Service, the application of the legislation was much more uneven. This was chiefly a result of the local cultural and political contexts that had to be contended with - not least the customary rights and practices of local populations. In some cases the laws were strongly opposed. In the Gold Coast, for example, while Thompson's Forest Bill was passed, after considerable amendment, by the Legislative Council in 1911, it met with strong resistance due to its interference with native land rights, and ultimately the legislation was not applied. ${ }^{90}$ Indeed, the resistance of local populations to the creation of forest reserves presented an increasing problem for colonial governance, and this contributed to changing attitudes towards customary rights and practices. It would again be in India that the precedents were set.

\section{Chotanagpur Tenancy Act 1908}

Forestry regulation generally sought to put a stop to indigenous methods of forest management such as shifting cultivation, which was regarded as wasteful and destructive. Despite this, it was argued that the interests of local agriculturalists were safeguarded during the creation of forest reserves through a variety of methods. Increasing incidents of agrarian discontent, however, suggest that the interests of small farmers living in forested areas were far from secure and this destabilization began to present a problem for colonial governance. A notorious case was the so-called Munda Rebellion of 1899-1900, a tribal resistance movement in the Chotanagpur region of Eastern India, led by the charismatic Birsa Munda. ${ }^{91}$ In the process of creating forest reservations, which were extensive in this region, the customary rights of local tribal groups had been disregarded and the indigenous population were coerced into bonded labour on the lands of the local zamindars and other non-tribal incomers. Birsa succeeded in uniting members of the aggrieved Munda tribal groups and a series of armed attacks were made on people and buildings associated with the colonial presence, including police stations and missions. The 'Ulgulan' or 'Great Tumult' was short-lived and soon dissipated after the imprisonment

\footnotetext{
88 H.N. Thompson, Gold Coast, Report on Forests (London, 1910).

$89 \mathrm{http}: / /$ www.cpbr.gov.au/biography/lane-poole-charles.html

${ }_{90}$ Richard Grove and Toyin Falola, 'Chiefs, Boundaries and Sacred Woodlands: Early Nationalism and the Defeat of Colonial Conservation in the Gold Coast and Nigeria, 1870-1916', African Economic History xxiv (1996), 1-23.

91 Kumar S. Singh, Bisra Munda and His Movement, 1872-1901: A Study of a Millenarian Movement in Chotanagpur (Calcutta, 2002).
} 
and death of Birsa Munda in 1900. While Birsa Munda was to become a cult figure in India's Indepenence movement, a more immediate response to the uprising was a review of forestry regulations in tribal areas and the passing of the Chotanagpur Tenancy Act of 1908. ${ }^{92}$

In the aftermath of the Munda Rebellion, the government was forced to make a survey of tribal land tenure (khuntkhatti) as a way of appeasing the Mundas and other tribal groups in Chotanagpur. It was felt, however, that a mere survey was inadequate, and it was necessary to secure the Mundas in their possession of the land. The Chotanagpur Tenancy Act provided legal recognition of Mundari khuntkhatti, and, at the same time, recognized that areas predominantly inhabited by tribal people required a separate system of administration and therefore excluded them from the normal government regulations, including the provisions of forestry law. These areas would come to be designated under the Government of India Act of 1919 as 'backward tracts', reflecting the perception that they were occupied by the most primitive tiers of the colonized society. ${ }^{93}$

The Chotanagpur Tenancy Act aimed to amend tenancy laws and codify them according to custom and usage. However, when the Act came into force there were only 156 villages registered as having full Mundari khuntkhatti rights. It was found that out of 3,614 square miles of cultivated land only 405 square miles qualified as ancestral property. ${ }^{94}$ From this we can conclude that the Act came too late, with the majority of Mundas already alienated from their lands. However, the Act had a greater symbolic significance since it recognised the Munda land system itself, which had been the subject of struggle long before the 1899-1900 uprising. The Jesuit missionary, John-Baptist Hoffmann, who spent much of his life working among the Mundas, saw the Act as a legitimation of the Munda's struggle and a recognition of the wisdom of their customary land rights system. Rather than the savages they had been regarded as being, Hoffmann argued that they were 'a race of martyrs' whose 'land system appears as one of the wisest creations of pre-historic times'. ${ }^{95}$

\section{Government of India (Excluded and Partially Excluded Areas) Order 1936}

In India, debates around the protection of tribal land rights and practices came to full term in the discussions instigated by the Indian Statutory Commission of 1928. This Parliamentary Commission was established to consult on and make recommendations for constitutional reform in India. When the Commission visited India, among the issues that they investigated was the matter of the 'backward tracts'. The Commission found that, excluding Burma, the extent of these tracts then amounted to 'no less than 120,000 square miles, containing a population of $11 \frac{114}{4}$ millions' ${ }^{96}$ In the context of their constitutional recommendations, while noting that the development of some designated tracts was now so advanced that 'special treatment' was no longer required, they generally concluded that

\footnotetext{
92 Space does not allow for a detailed discussion of what was in fact a very complex legislative process. See, however, S.P. Sinha, Conflict and Tension in Tribal Society (New Delhi, 1993), 30-90.

93 Uday Chandra, 'Liberalism and Its Other: The Politics of Primitivism in Colonial and Postcolonial Indian Law', Law and Society Review xlvii (2013), 147.

${ }_{94}^{4}$ Peter Tete, A Missionary Social Worker in India: J.B. Hoffmann, the Chota Nagpur Tenancy Act and the Catholic Co-operatives, 1893-1928 (Rome, 1984), 82.

95 John-Baptist Hoffmann, Encyclopaedia Mundarica viii (Patna, 1933), 2402.

${ }^{96}$ Report of the Indian Statutory Commission, Volume Two: Recommendations (New Delhi, 1930), 108.
} 
the majority should still 'be excluded from the general constitutional arrangements, and that special provision must be made for their administration' ${ }^{97}$ The grounds for these recommendations are discussed in the Commission's report:

The stage of development reached by the inhabitants of these areas prevents the possibility of applying to them methods of representation adopted elsewhere. They do not ask for self-determination, but for security of land tenure, freedom in the pursuit of their traditional methods of livelihood, and the reasonable exercise of their ancestral customs. Their contentment does not depend so much on rapid political advance as on experienced and sympathetic handling, and on protection from economic subjugation by their neighbours. ${ }^{98}$

The Commission recommended that backward tracts be redesignated as 'excluded areas', and that their administration be shifted from provincial authorities to central government. This was a significant proposal in the context of the devolution of power to Indian administrators that would result from the 1935 constitutional reforms. It effectively excluded Indians from administering these areas, suggesting that the safeguarding of indigenous interests could only be entrusted to Europeans. The idea of the colonial state as custodians of tribal land and the rights of indigenous peoples would impact on future constitutional developments and remained in force in post-Independence India until 1991, when all this was to change dramatically.

Elsewhere in the Empire similar trajectories were followed. Not only was forest legislation from India exported to other colonies, as we have seen, but the protection of tribes and their local customary rights also figured in these debates. This was often only articulated implicitly within the legislation. Thus the Lagos Colony's Forest Bill of 1902 recognized traditional land rights insofar as it required local chiefs to consent to the introduction of forestry regulations. Similarly, while Lane Poole's 1911 Sierra Leone Forestry Ordinance was based on the Indian Forest Act, the colonial authorities also made it clear that it was the government's policy 'to interfere as little as possible with tribal habits and customs', and to balance, on the one hand, improvement in agricultural methods so as to 'lessen the destruction of the forest and on the other hand to conserve existing forests and create new ones so as to preserve or restore ... the conditions to which the population is accustomed'. 99 Finally, in the Nigerian Forest Ordinance of 1916, Lugard built upon the innovations developed in Lagos, and introduced, as an experimental measure, the principle of the Native Administration of Forest Reserves, returning control, at least temporarily, to indigenous interest groups - albeit, as Grove and Falola note, with some unusual allies. ${ }^{100}$

\section{Conclusions}

\footnotetext{
97 Ibid. 109

98 Ibid.

99 Statement quoted in Barton, Empire Forestry, 108.

100 Grove and Falola, 'Chiefs, Boundaries and Sacred Woodlands', 16, 20.
} 
As we hope to have demonstrated in the above accounts, a spatio-temporal migration of sorts is discernible in the diffusion of cultural and natural heritage legislation in the British Empire. This was a result of various factors, including the application of the common legal practice of transplanting legislative interventions from one context to another in the drafting of new laws. While shortening what could otherwise be an expensive and protracted process, such as took place in the drafting of the Cyprus Antiquities Law of 1905, this also led to measures being introduced in colonial contexts where they were not necessarily appropriate. In some cases, such as in the Gold Coast and Sierra Leonean monuments ordinances, it enabled reluctant governments to pay legislative lipservice to Colonial Office directives, while introducing laws with little intention of providing the practical means of applying them. In other cases, on the contrary, an effective legislative framework was established in one colony that was then intentionally used as a model for a unified approach across multiple territories. Thus Wilhelm Schlich, in his Manual of Forestry, promoted an Empire-wide integration of forestry practices based on the approach pioneered in India. ${ }^{101}$ While many of these legislative interventions remain foundational to current postcolonial heritage laws, others might be better regarded - whether through over-reaching ambition or misalignment with local conditions - as failed experiments in the colonial legislative laboratory.

We have argued here that, while Indian legislation was also influenced by debates in other colonial territories, it was an important source for both natural and cultural heritage legislation. This is most apparent in the agency of celebrated figures such as Lord Curzon, whose passion for both the ancient monuments and 'natural contents' of Empire were forcefully expressed through often stringent legislative measures. As both restorer of the Taj Mahal and saviour of Tattershall Castle, promoter of both the Indian Ancient Monuments Act of 1904 and the English Ancient Monuments Consolidation and Amendment Act of 1913, Curzon was also a crucial bridge between cultural heritage debates in the colonies and the metropole. But we should remember that Curzon was neither the first nor the last such bridging figure in India or elsewhere. Indeed, just as the migration of heritage legislation was made possible through multiple circuits of colonial communication networks, it was also consequent upon the physical migrations of individuals, whose interests frequently bridged the worlds of cultural and natural heritage, as they moved between postings in different colonial territories within the various Imperial and Colonial services.

By reflecting on the perhaps unwitting protection of the customs and practices (what we now regard as intangible cultural heritage) of indigenous populations within migrations of natural heritage legislation, our discussion also provides a new perspective on familiar questions concerning colonial perceptions of the 'native peoples' of empire. Here, as in so many spheres of colonial thinking, we find contradictions and inconsistencies, but we also find a pattern in which the heritage of indigenous people itself migrates from the domain of natural heritage legislation to that of cultural heritage legislation. Thus, in their absence from the early cultural heritage legislation we find the posited status of natives as a 'people without history' confirmed. Indigenous populations were, rather, themselves considered 'a

101 W. Schlich, Schlich's Manual of Forestry. Volume I. Forest Policy in the British Empire, 3rd Edition (London, 1906). 
living memorial of the past'; ${ }^{\prime 102}$ a remnant of prehistory somehow related to the archaeological and palaeoanthropological discoveries that were then being excavated. As we have seen in the Southern Rhodesian context, as 'bushmen' and 'tribals', they were regarded as incapable of building architectural monuments worthy of preservation. Destined for extinction before the 'onward march of civilization', their way of life and material culture became the preserve of salvage ethnographers. Placed within their natural habitat, however, and 'tamed' (though military intervention, if necessary, as in the case of Chotanagpur), native populations were also ennobled and idealized, and the perceived wisdom of their innate custodianship of the environment was reified - not least, through the legislative measures we have discussed. As a vulnerable part of the 'natural contents' of Empire, then, they had to be protected from the culture (and laws) of the modern capitalist state. It was only in the 1940s, when les arts primitifs had become sought after within metropolitan art markets, that indigenous peoples' heritage became incorporated into cultural heritage preservation, and 'objects of ethnographical interest' were consequently reframed in the legislation as 'antiquities' and 'relics'. Finally, from the mid1970s, a more informed discourse began to emerge, in which natural and cultural, tangible and intangible were at last reunited in a new heritage paradigm, most explicitly articulated in South Africa's 1999 National Heritage Resources Act.

\section{Captions to Figures}

Figure 1: Comparative table attached to Legal Report on the Uganda Preservation of Archaeological Objects Ordinance of 1934, TNA, CO 536/181/14 (Uganda, 1934).

Figure 2: Comparative table attached to Legal Report on the Gold Coast Monuments and Relics Ordinance of 1945 (Research 28040/11/1946), TNA, CO 927/31/6.

102 Northcote W. Thomas, 'Editor's Preface', in Alice Werner, The Natives of British Central Africa (London, 1906), vi. 